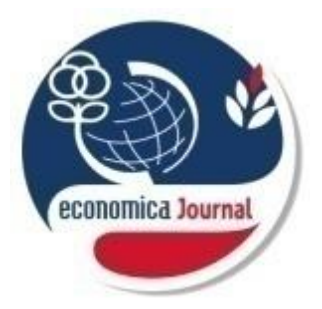

ISSN : $2302-1590$

E-ISSN: $2460-190 X$

\title{
ECONOMICA
}

\author{
Jurnal Program Studi Pendidikan Ekonomi \\ STKIP PGRI Sumatera Barat Vol.8 No.1 (51-59)
}

\section{INFLUENCE OF FUNDAMENTAL FACTORS ON STOCK RETURN LISTED IN JAKARTA ISLAMIC INDEX}

\author{
By \\ Iin Syofia Yandra'), Mohamad Fani Alfarisi' ${ }^{2)}$ \\ ${ }^{1)}$ Master of Management, Faculty of Economic, Andalas University \\ Email: iins95.isy@gmail.com \\ ${ }^{2}$ Lecturer, Faculty of Economic, Andalas University \\ Email: mfany@eb.unand.ac.id \\ Submited: 2019.09.26 Reviewed: 2019.10.14 Accepted:2019.10.30 \\ https://doi.org/10.22202/economica.2019.v8.i1.3618
}

\begin{abstract}
Stock return is the rate of return in a form of repayment from stock trade. This study was conducted to understand the influence of fundamental factor: Current Ratio (CR), Debt to Equity Ratio (DER), Return on Assets (ROA), Price Earning Ratio (PER), and Price to Book Value (PBV) to return stock. Sample in this study is the Jakarta Islamic Index (JII) in Indonesia Stock Exchange (IDX) during the research (2014-2017). Total sample in this study was 17 companies with purposive sampling technique. This study used panel data regression analysis, with some of choosing model Chow test, Hausman test, Lagrange multiplier test, and coefficient test with T-test to test coefficient regression partially, an F-test to test the influence at once with 5\% significance rate. The result showed that Current Ratio (CR), Debt to Equity Ratio (DER), Return on Assets (ROA), and Price to Book Value (PBV) has a positive and significant influence to return stock. Meanwhile, Price Earning Ratio (PER) has no significant effect to return stock. But, along with the independent variable, given the influence to return stock of Jakarta Islamic Index (JII) Indonesia Stock Exchange (IDX).

Jel Classification:

M42; F32

Keywords: Current Ratio, Debt to Equity Ratio, Return on Assets, Price to Book Value, Stock Return
\end{abstract}

C2019 Prodi Pendidikan Ekonomi STKIP PGRI, Padang 


\section{INTRODUCTION}

The development of Islamic capital markets in Indonesia, in general, is characterized by various indicators including the increasingly widespread Islamic capital market players issuing Islamic securities, namely shares incorporated in the Jakarta Islamic Index (JII). The Jakarta Islamic Index (JII) issued by the JSX is an index of 30 company shares whose activities are seen as not in conflict with the Shariah and evaluated every six months. In addition, the rise of the Islamic economy at the present time, demands a capital market that is affiliated with the Islamic economic system. The development of the sharia capital market shows progress along with the increasing index shown in the Jakarta Islamic Index (JII) for 2013-2017 as shown in Table 1 below :

Table 1. Sharia Stock Index Performance in JII in 2013-2017

\begin{tabular}{ccc}
\hline No & Year & JII \\
\hline 1 & 2013 & 585.11 \\
2 & 2014 & 691.04 \\
3 & 2015 & 603.35 \\
4 & 2016 & 694.13 \\
5 & 2017 & 759.07 \\
\hline
\end{tabular}

Source : www.ojk.go.id

From table 1, it can be seen that the shari'ah stock index generally increased from 2013 to 2017 except in 2015. Although the JII index generally increased, when compared to other stock groups such as the IHSG and LQ45, the percentage of the Index JII is still relatively low in 2013-2017. In investing in stocks, the hope that investors want is to get a return. The choice of investors for shares of companies incorporated in the Islamic stock group is also inseparable from the expected return. However, although investors can predict returns using the parameters of the company's fundamental factors, it is realized that investors are not easy in making investment portfolio decisions. As a result of the characteristics of each company, investors face difficulties in determining which fundamental corporate factors are dominant in affecting stock returns.

So, in this study the authors will analyze the factors that can affect stock returns by using company fundamental factors. The fundamental factor is a good measurement tool to be used as an analysis of a company's financial performance because it can determine the company's internal conditions. According to Van Horne (2013), fundamental factors are the main factors driving stock prices and with a good analysis of fundamental factors, investors can minimize risk while optimizing profits. Fundamental factors in this study are measured using liquidity ratios, solvency ratios, profitability ratios, and market value ratios. According to Gitmin (2009) The author chose this variable because ratio analysis is a tool that helps to analyze the company's financial statements so that we can find out the strengths and weaknesses of a company. In addition, with these financial ratios, investors can find out the company's growth both in terms of the benefits it has and the company's ability to fulfill all its responsibilities.

In a study conducted by Tamuunu and Rumokoy (2015) obtained the results that the Current Ratio had a positive and significant effect on stock returns. Abdullah et al (2018) in his research also stated that Debt to Equity Ratio had a positive and significant effect on stock returns. Furthermore, in research conducted by Muhammad and Scrimgeour (2014) obtained the results that Return On Assets has a positive and significant effect on stock returns. Whereas in the research 
conducted by Setiawan and Oktariza (2013) also obtained results that Price Earning Ratio had a positive and significant effect on stock returns. And also in a study conducted by $\mathrm{F}$ and Benazir (2015), it was found that Price to Book Value had a positive and significant effect on stock returns. Noting previous studies, research on the performance of sharia stocks is still relatively small, meanwhile data on sharia stock indexes in the Jakarta Islamic Index (JII) is always changing and tends to rise from year to year and plus Indonesia is a country with the most Muslim population in the world and also the global market that began to look at Indonesia in terms of Islamic financial markets, so it is necessary to do research on the performance of Islamic stocks in the Jakarta Islamic Index (JII). In addition, previous studies on the fundamental factors of companies that incorporate financial ratios have not been studied much about their influence simultaneously on Islamic stock returns in the Jakarta Islamic Index (JII). most previous research only examined the effect of these factors on conventional stock returns. Therefore, the authors are interested in researching more about Islamic stock returns and see the influence of the company's fundamental factors. Each proxy or measurement taken from the independent variable is Current Ratio (CR), Debt to Equity Ratio (DER), Return on Assets (ROA), Price Earning Ratio (PER), and Price to Book Value (PBV).

\section{METHODS}

In this study the population is all companies that issue Islamic shares on the Indonesia Stock Exchange which are listed in the Jakarta Islamic Index (JII) in 2014-2017. The 2014-2017 period (4 years) is used as the observation period because with this time span it is expected to be obtained sufficient number of research samples and can be generalized. The sample in this study was obtained using a purposive sampling method with several criteria, namely: 1) Companies registered in the Jakarta Islamic Index in a row from the period 2014 - 2017, 2) Companies that published a complete financial statement from the period 2014 - 2017 according to data which is needed in the research variables. Based on these criteria, the number of samples in this study were 17 companies registered in JII in 2014-2017.

The assumptions of the classical regression model are problems of normality, muliticolinierity, heteroscedasticity and autocorrelation. If all of these assumptions are met, it will produce a linear, unbiased and estimator that has a minimum variant called BLUE (Best Linear Unlimited Estimator). To find out whether the regression model really has a significant and representative relationship, the model must meet the classical assumption test, which includes the normality test, multicollinearity test, heteroscedasticity test, and autocorrelation test.

Panel data regression is a combination of time series data and cross section data. According to Gujarati and Porter (2012) panel data regression method has several advantages when compared to time series or cross section data, namely 1) Panel data is a combination of two time serries and cross section data capable of providing more data so that it will produce more degrees of greater freedom, 2) Data time series and cross section can overcome the problem if the information is combined due to the problem of omitting variables (ommitted variables).

The general model of panel data regression is as follows:

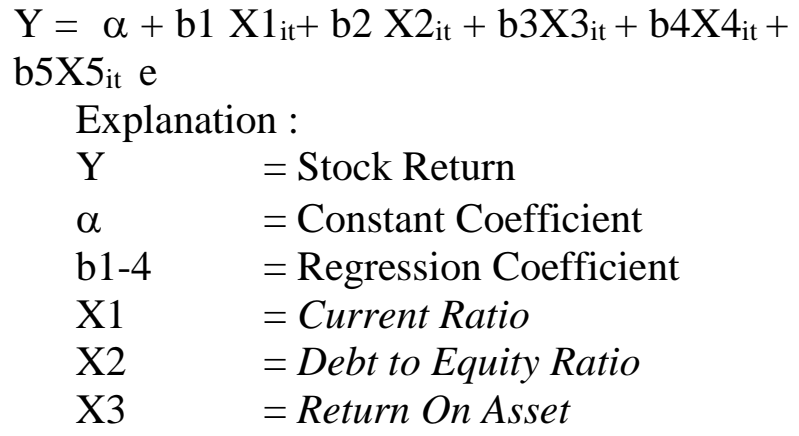




$$
\begin{aligned}
& \text { X4 = Price Earning Ratio } \\
& \text { X5 = Price to Book Value } \\
& \mathrm{e} \quad=\text { Standart Error } \\
& \mathrm{t}=\text { Time } \\
& \mathrm{i}=\text { Company }
\end{aligned}
$$

According to Gujarati and Porter (2012) there are three approaches in the method of estimating the regression model with panel data. First, the common effect model is the panel data model approach that combines time series data and cross sections without regard to time or individual dimensions. Second, the fixed effect model assumes that between individuals there are differences and can be accommodated from differences in their intercepts. Third, the random effect model is a panel data where interruption variables may be interconnected between time and between individuals.

To get the most appropriate model to be used in research, several tests are needed, namely 1) The Chow Test is a test to determine the Common effect or Random Effect model that is most appropriate to be used in estimating panel data. In the chow test, the data is regressed by using the common effect and fixed effect first then making a hypothesis to be tested. 2) Hausman Test is a statistical test to choose whether the Fixed Effect or Random Effect model is the most appropriate to use. To test it, the data is also revised first by using a random effect model then comparing the fixed effect with the random effect. 3) Lagrange Multiplier Test to find out whether the Random Effect model is better than the Common Effect (OLS) method using the Lagrange Multiplier (LM) test. The LM test is based on the chisquares distribution with degrees of freedom equal to the number of independent variables. If the LM statistical value is greater than the critical value of chi squares, the random effect is more appropriate and vice versa.

\section{RESULTS AND DISCUSSION Classic Assumption Test}

Before testing the next stage, normality testing is first performed. Normality testing aims to determine the pattern of variance diversity that is owned by each research variable. Every variable that will be formed into a regression model must first be normally distributed. In this study normality testing was performed using the Jurgue Fallow Test. Where each variable will be normally distributed if it has a probability above 0.05 .

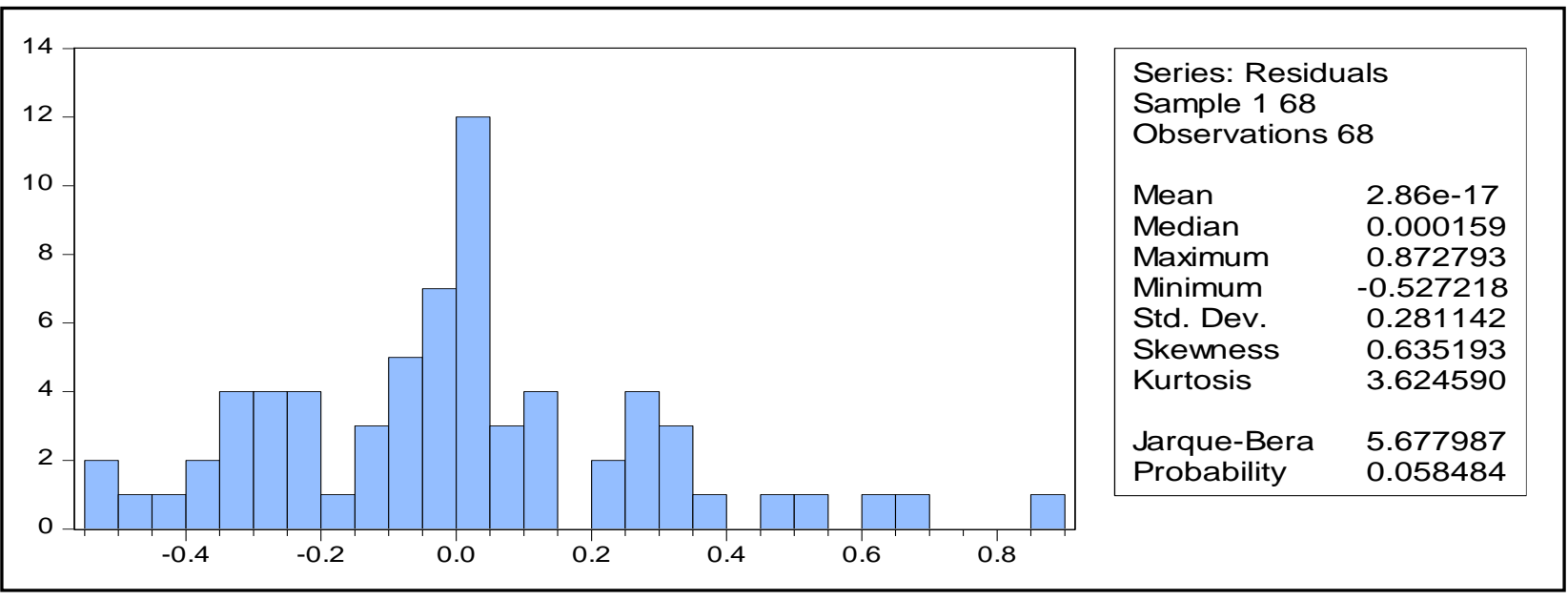

Figure 1. Residual Normality Test

Based on the residual normality test, the probability value of 0.058484 is obtained above 0.05 so that it can be concluded that all research variables are normally distributed, therefore further data processing can be done. 


\section{Multicollinearity Test}

Multicollinearity testing is done to test the relationship between independent variables. To detect the presence or absence of multicollinearity problems in this study is to look at the value of Centered Variance
Inflation Factor (VIF). If VIF> 10, then there is multicollinearity between independent variables. Conversely, if VIF < 10, then there is no multicollinearity between independent variables.

Table 2. Muliticolonierity Test Results

\begin{tabular}{ccc}
\hline Variable & Coefficient Variance & Centered VIF \\
\hline CR & 0.002326 & 1.225465 \\
DER & 0.010663 & 1.547309 \\
ROA & 1.393492 & 2.436466 \\
PER & $3.87 \mathrm{E}-05$ & 1.794078 \\
PBV & 0.001352 & 3.072379 \\
\hline
\end{tabular}

Source: Processed Secondary Data

From table 2, it can be seen that each variable has no multicollinearity problem, it is seen from the VIF value on the centered VIF on three independent variables less than 10 . Based on this, it can be concluded that each independent variable does not occur multicollinearity problems.

\section{Heteroscedasticity Test}

In detecting the presence or absence of heteroscedasticity problems, this study used the White Test model. In this model, the symptoms of heteroscedasticity will not occur if the probability value generated in the test is above 0.05 .

Table 3. Heteroscedasticity Test Results

\begin{tabular}{cccc}
\hline F-statistic & 1.256109 & Prob. F(20,47) & 0.2550 \\
\hline Obs*R-squared & 23.68631 & Prob. Chi-Square(20) & 0.2564 \\
\hline
\end{tabular}

Source: Processed Secondary Data

Based on the test results in table 3, it was found that there was no heteroscedasticity problem. This is because the value of Obs * $\mathrm{R}$ squared is 23.68631>0.05 and Prob value. Chi-Square (20) is $0.2564>0.05$, so it can be concluded that all variables used in this study are free from heteroscedasticity symptoms.

\section{Autocorrelation Test}

To find out whether in the regression model that is formed whether or not there are autocorrelation symptoms, autocorrelation testing is performed using the Durbin Watson (DW) test.

Table 4. Autocorrelation Test Results

\begin{tabular}{ccc}
\hline $\mathrm{R}$ - squared & Adjusted R- squared & Durbin Watson Stat \\
\hline 0.678913 & 0.620761 & 2.379161 \\
\hline
\end{tabular}

Source: Processed Secondary Data 
Based on table 4, it can be seen the value of Durbin Watson stat is 2.379161. Where the Durbin Watson stat produced is $1.73<\mathrm{DW}$ $<2.46(1.73<2.379161<2.46)$. So it can be concluded that all variables in this study which constitute pooling data are free from autocorrelation symptoms.

\section{Panel Data Regression} Chow Test

Chow test is a test to determine whether the fixed effect or random effect model is the most appropriate for estimating panel data.

Table 5. Chow Test Results

\begin{tabular}{cccc}
\hline Effects Test & Statistic & d.f. & Prob. \\
\hline Cross-section Chi-square & 23.534014 & 16 & 0.1002 \\
\hline
\end{tabular}

Source: Processed Secondary Data

Based on the results of the chow test in table 5 shows that the cross section probability value is 0.1002 or $>0.05$, it can be concluded that $\mathrm{H} 0$ is accepted and $\mathrm{H} 1$ is rejected. This means that the fixed effect model is not accepted.

\section{Hausman Test}

The Hausman Test is a statistical test to choose whether the Fixed Effect or Random Effect model is the most appropriate.

Table 6. Hausman Test Results



Source: Processed Secondary Data

Based on table 7, the Adjusted R-Square (R2) value is 0.620761 . This shows that the percentage influence of the variable Current
Ratio (CR), Debt to Equity Ratio (DER), Return On Assets (ROA), Price Earning Ratio (PER), and Price to Book Value (PBV) on the 
Stock Return variable is $62.08 \%$. Or it can be interpreted that the independent variable used in the model is able to explain at $62.08 \%$ of the dependent variable.

\section{Feasibility Test (F-Statistic Test)}

The F-statistic test aims to see whether all independent variables influence the dependent variable or to find out whether the regression model can be used to predict the dependent variable or not.

Table 8. F-Statistic Test Results

\begin{tabular}{cccc}
\hline F-statistik & Prob (F-statistik) & Alpha & Kesimpulan \\
\hline 17.79626 & 0.000000 & 0,05 & Signifikan \\
\hline
\end{tabular}

Source: Processed Secondary Data

Based on table 4.15 it can be seen that the test results show a probability value (Fstatistic) of 0.000000 . The error rate used is 0.05 . The results obtained indicate that the resulting probability value of $0.000000<$ alpha 0.05 , the decision is $\mathrm{HO}$ rejected and $\mathrm{Ha}$ accepted.

\section{Individual Significance Test (t-Statistic Test)}

The t-statistic test was used to prove the effect of each independent variable individually on the dependent variable with an alpha significance level of 0.05 .

Table 9. t-Statistic Test Results

\begin{tabular}{ccccccc}
\hline Variable & Coefficient & Std. Error & t-Statistic & Prob. & Alpha & Conclusion \\
\hline C & -0.429762 & 0.188370 & -2.281481 & 0.0260 & 0.05 & \\
CR & 0.122244 & 0.047095 & 2.595690 & 0.0118 & 0.05 & Significant \\
DER & 0.185220 & 0.100832 & 1.836915 & 0.0510 & 0.05 & Significant \\
ROA & 3.072421 & 1.152702 & 2.665408 & 0.0098 & 0.05 & Significant \\
PER & 0.002101 & 0.006075 & 0.345787 & 0.7307 & 0.05 & Not Significant \\
PBV & 0.128159 & 0.035910 & 3.568894 & 0.0000 & 0.05 & Significant \\
\hline
\end{tabular}

\section{Source: Processed Secondary Data}

Based on table 9, the first hypothesis is obtained the t-statistic Current Ratio (CR) is 2.595690 with a probability value of 0.0118 , where the probability value is smaller than the 0.05 alpha significance level. This means that Current Ratio (CR) has a positive and significant effect on stock returns. With this positive and significant influence indicates that if the Current Ratio (CR) increases, stock returns will also increase, conversely if the Current Ratio (CR) decreases, the stock returns listed in JII in the 2014-2017 period will also decrease.

The second hypothesis is obtained the tstatistic Debt to Equity Ratio (DER) is 1.836915 with a probability value of 0.0510 , where the probability value is smaller than the alpha significance level of 0.05 . This means that Debt to Equity Ratio (DER) has a positive and significant effect on stock returns. With this positive and significant influence indicating that if Debt to Equity Ratio (DER) increases, stock returns will also increase, conversely if Debt to Equity Ratio (DER) decreases, stock returns listed in JII in the 2014-2017 period will also decreased.

The third hypothesis is that the Return on Assets (ROA) t-statistic is 2.665408 with a probability value of 0.0098 , where the probability value is smaller than the 0.05 alpha significance level. This means that Return On Assets (ROA) has a positive and significant effect on stock returns. The positive and significant influence indicates that if Return On Assets (ROA) increases, stock returns will also increase, conversely if Return On Assets 
(ROA) decreases, stock returns listed in JII in the 2014-2017 period will also decrease.

The fourth hypothesis is obtained by the t-statistic Price Earning Ratio (PER) of 0.345787 with a probability value of 0.7307 , where the probability value is greater than the 0.05 alpha significance level. This means that Price Earning Ratio (PER) has a positive and not significant effect on stock returns. With this positive influence indicates a direct relationship between the value of Price Earning Ratio (PER) and stock returns listed in JII in the 2014-2017 period. With insignificant influence shows that in investing investors do not pay attention to the value of Price Earning Ratio (PER) as one of the considerations in making investment decisions.

The fifth hypothesis is obtained the Price to Book Value (PBV) t-statistic is 3.568894 with a probability value of 0.0000 , where the probability value is smaller than the 0.05 alpha significance level. This means that Price to Book Value (PBV) has a positive and significant effect on stock returns. With this positive and significant influence indicating that if Price to Book Value (PBV) increases, stock returns will also increase, conversely if Price to Book Value (PBV) decreases, stock returns listed in JII in the 2014-2017 period will also decreased.

\section{CONCLUSION}

From the results of t-statistical hypothesis testing, it can be concluded that the first hypothesis was accepted, where the result showed that variable Current Ratio have a positive and significant effect on the return of Shariah shares listed in JII 2014-2017. The second hypothesis was accepted, where the result showed that variable Debt to Equity Ratio have a positive and significant effect on the return of Shariah shares listed in JII 20142017. The third hypothesis was accepted, where the result showed that variable Return On Assets have a positive and significant effect on the return of Shariah shares listed in JII
2014-2017. The fourth hypothesis was rejected, where the result showed that variable Price Earning Ratio partially has not significant influence on the return of Shariah shares listed in the JII 2014-2017 period. The fifth hypothesis was accepted, where the result showed that variable Price to Book Value partially have a positive and significant effect on the return of Shariah shares listed in JII 2014-2017.

Based on the results of the F-statistical hypothesis testing, the variable Current Ratio, Debt to Equity Ratio, Return On Assets, Price Earning Ratio and Price to Book Value simultaneously have a significant effect on syari'ah stock returns listed in JII 2014-2017. Furthermore, based on the results of the coefficient of determination test, the variable Current Ratio, Debt to Equity Ratio, Return On Assets, Price Earning Ratio and Price to Book Value are able to explain the variable returns of shari'ah shares listed in the JII 2014-2017 period amounting to $62.08 \%$. While the remaining $37.92 \%$ is influenced by other factors outside the regression model not examined in this study.

\section{REFFERENCE}

Abdullah, Ujang et al. 2018. The Factors Wich Influence Stock Return With Stock Price As Moderating Variable in Automotive Companies Listed in The Indonesia Stock Exchange. International Journal of Research and Review, Vol.5 No. 10

Gitman, Lawrence. 2009. Principles of Manajerial Finance. United States: Pearson Addison Wesley.

Gujarati, Damodar N. dan Dawn C. Porter. 2012. Basic Econometrics. 5th Edition. New York: McGraw Hill.

Majid, M. Shabri Abd. and Benazir. 2015. An Indirect Impact of the Price to Book 
Value to the Stock Returns: An Empirical Evidence from the Property Companies in Indonesia. Jurnal Akuntansi dan Keuangan, Vol. 17 No. 2

Muhammad, Noor and Frank Scrimgeour. 2014. Stock Returns and Fundamentals in the Australian Market. Asian Journal of Finance and Accounting, Vol. 6 No.1

Setiawan, Chandra and Hesty Oktariza. 2013. Syariah and Conventional Stocks Performance of Public Companies Listed on Indonesia Stock Exchange. Journal of Accounting, Finance and Economics, Vol. 3 No. 1

Tamuunu, Sonnia Cindy and Farlane Rumokoy. 2015. The Influence Of Fundamental Factors On Stock Return (Case Study: Company Listed In LQ45 2011-2014). Jurnal Emba, Vol. 3 No. 4

Tandelilin, Eduardus. 2010. Analisis Investasi dan Manajemen Portofolio. Yogyakarta : BPFE.

Van Horne, James C. and John M. Wachowicz. 2013. Fundamental of Financial Management. 13th Edition. United Kingdom: Pearson Education. 